\title{
Pengaruh Perputaran Modal Kerja Terhadap Profitabilitas Pada Perusahaan Manufaktur LQ-45 Periode 2015-2017
}

\author{
Suci Rizky Amelia dan Lukman Cahyono \\ Program Studi Akuntansi, STIE Bhakti Prasetya Karya Praja (BPKP), Jakarta-Indonesia
}

lukman.cahyonomb@gmail.com

How to cite (in APA style):

Amelia, S. R., \& Cahyono, L. (2020). Pengaruh Perputaran Modal Kerja Terhadap Profitabilitas Pada Perusahaan Manufaktur LQ-45 Periode 2015-2017. Wacana Ekonomi (Jurnal Ekonomi, Bisnis dan Akuntansi). 19(2), pp.114-122. https://doi.org/10.22225/we.19.2.1967.114-122

\begin{abstract}
The purpose of this study was to analyze variables of working capital consists of cash turnover, receivables turnover, and inventory turnover on the Profitability. Profitability is measured by the proxy of return on assets. The study population used observational data in the manufacturing sector with the LQ-45 index listed on the Indonesia Stock Exchange in the 2015-2017 period of 10 companies. The research method uses an analysis multiple linear regression, classic assumptions test which include the normality, multicollinearity, heteroscedasticity and Autocorrelation tests, with hypothesis tests. The results showed that working capital variables (cash turnover, receivables turnover, and inventory turnover) has simultaneous influence to the Profitability. Working capital, namely is only cash turnover has a significant influence to the profitabilit mean while receivables turnover and inventory turnover have no influence to the profitability.
\end{abstract}

Keywords: Working Capital, Cash Turnover, Profitability.

\begin{abstract}
Abstrak
Tujuan penelitian ini adalah untuk menganalisis variabel-variabel modal kerja yaitu Perputaran Kas, Perputaran Piutang, dan Perputaran Persediaan terhadap Profitabilitas. Profitabilitas diukur dengan proksi Return On Assets. Populasi penelitian menggunakan data observasi pada sektor manufaktur dengan indeks LQ-45 yang terdaftar di Bursa Efek Indonesia periode 2015-2017 sebanyak 10 perusahaan. Metode penelitian menggunakan analisis regresi linier berganda, pengujian asumsi klasik yang meliputi: Uji Normalitas, Multikolinearitas, Heteroskedastisitas serta Uji Autokorelasi, dan Uji Hipotesis. Hasil penelitian menunjukkan bahwa variabelvariabel Modal Kerja (Perputaran Kas, Perputaran Piutang, dan Perputaran Persediaan) berpengaruh signifikan secara simultan terhadap Profitabilitas. Variabel Modal Kerja yaitu Perputaran Kas yang hanya berpengaruh signifikan terhadap Profitabilitas, sementara Perputaran Piutang dan Perputaran Persediaan tidak berpengaruh signifikan terhadap Profitabilitas.
\end{abstract}

Kata Kunci: Modal Kerja, Perputaran Kas, Profitabilitas.

\section{PENDAHULUAN}

Persaingan dunia usaha saat ini begitu ketat dan kompetitif, hal ini menyebabkan banyak perusahaan kesulitan mempertahankan usahanya. Untuk itu para pelaku ekonomi di Indonesia dituntut untuk segera menyesuaikan diri dengan perubahan yang terjadi agar dapat bersaing. Perusahaan harus dapat membuktikan profesionalismenya dan kinerja yang baik untuk dapat bersaing di pasar global. Perusahaan dituntut juga harus inovatif dan mampu menyesuaikan diri dengan perubahan yang terjadi dan yang akan terjadi di lingkungannya, baik perubahan ekonomi nasional, Peraturan Pemerintah, kondisi konsumen maupun kemampuan pesaing (Prasetyono, 2017). Oleh karenanya perusahaan dituntut tumbuh dan berjalan, secara konsepsional dan sistematis dikelola yang dapat memanfaatkan seluruh potensi sumber daya perusahaan yang berorientasi pada pertumbuhan, perkembangan dan going-concern perusahaan (Novianti, 2016). Untuk mewujudkan semua tuntutan tersebut diperlukan struktur pengelolaan yang efektif, efisien dan produktif terhadap semua bagian yang ada pada perusahaan.

Manajemen harus dapat mengambil keputusan yang tetap dan harus dapat menetapkan kebijakan-kebijakan yang tepat dan strategis. Semua tindakan tersebut dilakukan dengan tujuan agar perusahaan mampu meningkatkan kinerjanya. Salah satu faktor penting yaitu modal kerja, 
perusahaan dalam membiayai pengeluaran-pengeluaran operasi rutin, seperti pembelian bahan baku, bahan baku tambahan, pembayaran upah atau gaji pegawai, dan lain sebagainya membutuhkan modal kerja. Modal kerja yang tersedia harus cukup dan juga dapat menjaga perusahaan terhadap kemungkinan terjadinya krisis modal kerja akibat turunnya aktiva lancar dan dari kesulitan kondisi keuangan yang nanti akan timbul kedepannya.

Modal kerja adalah investasi sebuah perusahaan pada aktiva-aktiva jangka pendek kas, suratsurat berharga, persediaan dan piutang. Bagi suatu perusahaan, masalah modal kerja (working capital) merupakan suatu hal penting yang memerlukan perhatian besar dan tindakan yang hati-hati dalam pengelolaannya (Fahmi, 2015, hal. 100). Sumber-sumber modal kerja dapat menggunakan modal sendiri (intern) atau pinjaman dari pihak lain (ekstern) untuk menghasilkan likuiditas atau perputaran kas perusahaan walaupun memiliki dilema dalam keterbatasan pada jumlahnya, sedangkan kebutuhan yang sangat besar untuk pembiayaan modal kerja berasal dari pinjaman.

Modal kerja pada sebuah perusahaan biasanya terdiri dari 3 (tiga) komponen utama yaitu kas, piutang dan persediaan. Kas adalah aset perusahaan yang paling likuid dan karena itu dicantumkan pada urutan aset yang pertama dalam kelompok aset lancar. Jadi, rasio perputaran kas ini bermanfaat untuk mengukur tingkat kecukupan modal kerja perusahaan yang dibutuhkan membayar tagihan dan membiayai penjualan (Lestari \& Farida, 2017).

Selain komponen kas, faktor lainnya yang mempengaruhi jumlah modal kerja adalah piutang. Piutang merupakan bentuk penjualan yang dilakukan olehsuatu perusahaan dimana pembayarannya tidak dilakukan secara tunai, namun bersifat bertahap. Hubungan penjualan kredit dan piutang usaha dinyatakan sebagai perputaran piutang. Rasio ini dihitung dengan membandingkan antarapenjualan kredit bersih dengan rata-rata piutang bersih (Kasmir, 2016). Contohnya pada piutang dagang, bila piutang ini banyak yang tidak tertagih maka modal kerja akan terganggu perputarannya. Mengingat pentingnya modal kerja bagi kelancaran operasi perusahaan, maka peran manajemen dalam menerapkan kebijakan-kebijakan sehubungan dengan modal kerja yang tersedia sangat diperlukan agar kebijakan besarnya modal kerja atau aktiva lancar yang harus dipertahankanmencukupi biaya operasi.

Modal kerja penting lainnya setelah kas dan piutang adalah persediaan yaitu sejumlah barang jadi, bahan baku, barang dalam proses yang dimiliki perusahaan dengan tujuan untuk dijual atau diproses lebih lanjut. Pengendalian persediaan yang efektif diperlukan untuk memelihara jumlah, jenis dan kualitas barang yang sesuai dan mengatur investasi dalam persediaan (Lestari \& Farida, 2017). Perputaran persediaan adalah menunjukkanseberapa cepat perputaran persediaan dalam siklus produksi normal. Dengan mengetahui tingkat perputaran masing-masing komponen modal kerja diharapkan dapat memberikan informasi yang lebih akurat kepada pihak yang berkepentingan sehingga akan lebih bermanfaat lagi dalam pengambilan kebijakan yang dilakukan oleh manajemen (Harahap, 2018, hal. 308)

Pengambilan kebijakan yang tepat diharapkan kemampuan perusahaan untuk menghasilkan laba (profit) akan semakin meningkat. Lebih lanjut, tingkat perputaran masing-masing komponen modal kerja ini dapat dibandingkan dengan perusahaan lain dalam industri sejenis atau dengan ratarata perputaran komponen modal kerja yang terdapat dalam suatu industri sehingga akan memberikan gambaran kepada manajer bagaimana kinerja perusahaan yang dikelolanya dibandingkan dengan perusahaan lain ataupun rata-rata industri dimana perusahaan tersebut berada (Arik Santini \& Baskara, 2018).

Seiring dengan perkembangan dan usaha yang semakin pesat di Indonesia, ini diperlukan perencanaan yang baik agar perusahaan dapat menjalankan usaha dengan lancar dan berhasil untuk mencapai tujuan. Untuk mencapai suatu tujuan yang baik, seharusnya perusahaan menjalankan perencanaan perusahaan yang disusun dengan konsep dasar dan prosedur yang telah digambarkan oleh suatu perusahaan yang bersangkutan.

Menurut American Institute of Certified Public Accounting (AICPA), "Akuntansi sebagai seni pencatatan, penggolongan, dan pengikhtisaran dengan cara tertentu dalam ukuran moneter, transaksi, dan kejadian-kejadian yang umumnya bersifat keuangan termasuk menafsirkan hasilhasil" (Harahap, 2018, hal. 3). Penyajian akun kas, piutang dan persediaan untuk mengukur modal kerja dituangkan dalam laporan keuangan yaitu di neraca. Laporan keuangan merupakan suatu informasi yang menggambarkan kondisi keuangan suatu perusahaan, dan lebih jauh informasi tersebut dapat dijadikan sebagai gambaran kinerja keuangan perusahaan tersebut (Fahmi, 2015, hal. 
2).

Accounting Principle Board Statement No. 4 menyatakan bahwa tujuan laporan keuangan yaitu menyajikan posisi keuangan, hasil usaha, dan perubahan posisi keuangan lainnya secara wajar dan sesuai dengan prinsip-prinsip akuntansi yang berlaku umum. Dengan demikian bahwa pengguna informasi akuntansi harus dapat memperoleh pemahaman mengenai kondisi keuangan dan hasil operasional perusahaan lewat laporan keuangan (Hery, 2014, hal. 55). Tujuan akuntansi untuk menyiapkan laporan keuangan yang akurat sehingga dapat digunakan oleh manajer, pembuat kebijakan, dan pihak berkepentingan lainnya, seperti pemegang saham, kreditor, atau pemilik (Isfani, Dewi, \& Husain, 2019).

Faktor utama yang memperoleh perhatian khusus dalam analisis laporan keuangan adalah likuiditas, solvabilitas, rentabilitas atau profitabilitas dan stabilitas usaha. Modal kerja penting dalam pengelolaan kas agar sesuai dengan kebutuhan perusahaan, maka kas harus diputar dengan baik. Tingkat perputaran kas akan berdampak langsung terhadap keuntungan. Tingkat perputaran kas merupakan ukuran efisiensi penggunaan kas yang dilakukan oleh perusahaan karena tingkat perputaran kas menggambarkan kecepatan arus kas kembalinya kas yang telah ditanamkan di dalam modal kerja (Sufiana \& Purnawati, 2013). Semakin tinggi tingkat perputaran kas berarti semakin tinggi efisiensi penggunaan kasnya dan semakin cepat kembalinya kas masuk pada perusahaan. Dengan demikian, kas akan dapat dipergunakan kembali untuk membiayai kegiatan operasional sehingga tidak mengganggu kondisi keuangan perusahaan.

Modal kerja penting dalam pengelolaan piutang agar sesuai dengan kebutuhan perusahaan, dimana keberadaannya sangat terkait dengan volume penjualan kredit. Timbulnya piutang disebabkan oleh penjualan barang-barang secara kredit dan hasilnya yaitu penjualan kredit neto dibagi dengan piutang rata-rata. Nilai dari perputaran piutang tergantung dari syarat pembayaran piutang tersebut, makin lunak atau makin lama syarat pembayaran yang ditetapkan berarti makin lama modal terikat dalam piutang. Posisi piutang dan taksiran waktu pengumpulannya dapat dinilai dengan menghitung tingkat perputaran piutang (Munawir, 2010, hal. 403). Adakalanya angka penjualan kredit untuk suatu periode tertentu tidak dapat diperoleh sehingga yang digunakan sebagai penjualan kredit adalah angka total penjualan. Jumlah hari penjualan dalam piutang memberi tolak ukur mengenai lamanya waktu piutang dagang yang beredar.Semakin besar rasio umur piutang semakin besar rasio tidak tertagihnya piutang.Perubahan rasio antara penjualan kredit dan rata-rata piutang disebabkan oleh banyak hal, diantaranya: (i) turunnya penjulan dan naiknya piutang diikuti turunnya penjualan dalam jumlah yang lebih besar serta naiknya piutang dalam jumlah yang lebih besar; (ii) turunnya penjualan dengan piutang tetap; dan (iii) naiknya piutang sedangkan penjualan tidak berubah.

Modal kerja penting dalam pengelolaan persediaan merupakan salah satu aktiva paling aktif dalam operasi kegiatan perusahaan. Di samping itu, persediaan juga merupakan aktiva lancar terbesar bagi perusahaan manufaktur maupun perusahaan dagang. Persediaan adalah aset: (a) tersedia untuk dijual dalam kegiatan usaha normal; (b) dalam proses produksi atau dalam perjalanan; dan (c) dalam bentuk bahan atau perlengkapan untuk digunakan dalam proses produksi ataupun pemberian jasa (IAI, 2013, hal. 143). Perubahan dalam akuntansi persediaan diikuti dengan sistem pencatatan pada rekening persediaan sehingga sewaktu-waktu dapat diketahui jumlah persediaan dengan cara melihat kolom saldo dalam rekening persediaan (Maesaroh \& Dewi, 2020).

Rasio Profitabilitas adalah rasio utama dalam seluruh laporan keuangan karena tujuan utama perusahaan adalah hasil operasi atau keuntungan. Rasio Profitabilitas merupakan rasio yang mengukur mengukur efektivitas manajemen secara keseluruhan yang ditujukan oleh besar kecilnya tingkat keuntungan yang diperoleh dalam hubungannya dengan penjualan maupun investasi. Semakin baik rasio profitabilitas maka semakin baik menggambarkan kemampuan tingginya perolehan keuntungan perusahaan (Fahmi, 2015, hal. 80). Efektifitas manajemen disini dilihat dari laba yang dihasilkan terhadap penjualan dan investasi perusahaan. Keuntungan adalah hasil akhir dari kebijakan dan keputusan yang diambil oleh manajemen serta kemampuan perusahaan dalam mendapatkan laba melalui semua kemampuan dan sumber yang ada seperti kegiatan penjualan, kas, modal, jumlah karyawan, jumlah cabang dan sebagainya (Harahap, 2018, hal. 308). Kebijakan pengukuran kinerja dalam suatu perusahaan yang didasarkan atas perhitungan keuntungan usaha yang dihasilkan oleh nasabah dengan return kepada investor berupa feedback rate tidak hanya berdasarkan pendapatan atau penjualan (Yanti, 2018).

Pengukuran rasio profitabilitas secara umum terdapat 4 (empat) yang digunakan untuk menilai 
tingkat profitabilitas yakni Gross Profit Margin (Margin Laba Kotor), Net Profit Margin (Margin Laba Bersih), Return On Assets (ROA), dan Return On Equity (ROE). Return on A ssets (ROA) juga menjadi pengukuran profitabilitas yang banyak digunakan oleh peneliti kemudian juga Return on Equity (ROE), kedua rasio ini menggambarkan daya tarik investasi (Husain, Sarwani, Sunardi, \& Lisdawati, 2020).

Beberapa penelitian terdahulu yang dirujuk yaitu: (1) Pengaruh perputaran kas, perputaran piutang, dan perputaran persediaan terhadap profitabilitas pada perusahaan food and beverages di Bursa Efek Indonesia periode 2008-2010 dengan metode analisis regresi linier berganda. Hasil penelitian membuktikan secara simultan ketiga rasio perputaran di atas yakni kas, piutang dan persediaan atas profitabilitas sementara pada uji parsial hanya perputaran piutang dan persediaan yang berpengaruh terhadap profitabilitas (Sufiana \& Purnawati, 2013). (2) Pengaruh struktur aktiva dan pertumbuhan penjualan terhadap struktur modal (DAR) pada perusahaan retail yang terdaftar di Bursa Efek Indonesia periode 2012-2016 dengan menggunakan regresi data panel. Hasil penelitian membuktikan secara simultan dan parsial struktur aktiva dan ukuran perusahaan berpengaruh terhadap struktur modal dengan pengukuran utang jangka panjang dengan modal sendiri (Novianti, 2016). (3) Pengaruh antara biaya CSR (corporate social responsibility) ukuran perusahaan, leverage dan growth terhadap profitabilitas Perusahaan Pertambangan yang terdaftar di Bursa Efek Indonesia Periode Tahun 2009-2013 dengan analisis regresi berganda. Hasil penelitian membuktikan secara simultan atas pengaruh biaya CSR, ukuran perusahaan, leverage dan growth terhadap profitabilitas, sementara hanya ukuran perusahaan yang secara parsial berpengaruh terhadap profitabilitas (Cahyono, 2016). (4) Pengaruh modal kerja terhadap profitabilitas pada industri Makanan dan Minuman yang terdaftar di Bursa Efek Indonesia periode 2010-2014 dengan metode analisis regresi linier berganda. Hasil penelitian membuktikan secara simultan ketiga rasio perputaran di atas yakni kas, piutang dan persediaan atas profitabilitas sementara pada uji parsial hanya perputaran persediaan yang berpengaruh terhadap profitabilitas (Lestari \& Farida, 2017). (5) Pengaruh perputaran modal kerja, ukuran perusahaan dan likuiditas terhadap profitabilitas Perusahaan Tekstil dan Garmen periode 2014-2016 dengan teknik analisis regresi linier berganda. Hasil penelitian membuktikan bahwa perputaran modal kerja dan likuiditas berpengaruh positif dan signifikan sementara ukuran perusahaan tidak berpengaruh signifikan terhadap profitabilitas (Arik Santini \& Baskara, 2018).

Temuan penelitian di atas melatarbelakangi merumuskan kajian lebih lanjut mengenai pentingnya faktor modal kerja yang terdiri dari perputaran kas, perputaran piutang dan perputaran persediaan dalam memprediksi profitabilitas perusahaan.Oleh karena itu, diperlukan kerangka berpikir yang membentuk sintesa yang mencerminkan keterkaitan antara variabel yang diteliti dan merupakan tuntunan untuk memecahkan masalah penelitian serta merumuskan hipotesis penelitian yang dilengkapi penjelasan kualitatif (Sugiyono, 2018).

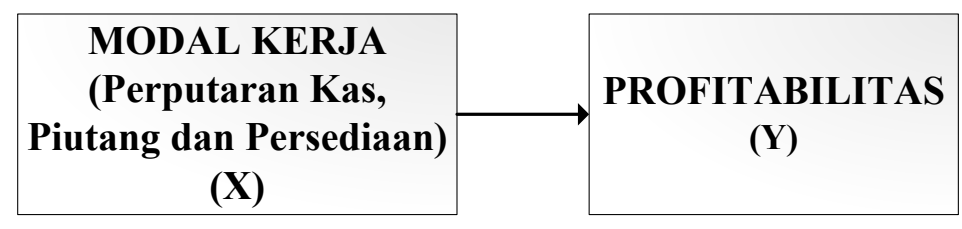

Gambar 1

Kerangka Penelitian

Hipotesis penelitian ini dirumuskan sebagai berikut:

$\mathrm{H}_{0}$

, Modal Kerja tidak berpengaruh signifikan terhadap Profitabilitas

$\mathrm{H}_{\mathrm{a}}$

, Modal Kerja berpengaruh signifikan terhadap Profitabilitas, yang diturunkan menjadi beberapa hipotesis alternatif berikut ini:
$\mathrm{H}_{1}$
, Perputaran Kas berpengaruh signifikan terhadap Profitabilitas
$\mathrm{H}_{2}$
, Perputaran Piutang berpengaruh signifikan terhadap Profitabilitas
$\mathrm{H}_{3}$
, Perputaran Persediaan berpengaruh signifikan terhadap Profitabilitas 


\section{METODE}

Jenis penelitian ini adalah riset kausalitas yang bertujuan untuk menguji hipotesis tentang pengaruh satu variabel atau beberapa variabel (variable independent) terhadap variabel lainnya/ variabel dependent (Sugiyono, 2018, hal. 62). Penelitian ini menggunakan pendekatan kuantitatif dengan riset survei atas laporan keuangan dengan variabel independen yaitu perputaran modal kerja dan profitabilitas perusahaan.

Penelitian dilakukan di Bursa Efek Indonesia (BEI) yang beralamat di Gedung Bursa Efek Indonesia, Tower 1 - Lantai 6, Jl. Jend Sudirman Kav. 52-53, Jakarta Selatan - 12190, Indonesia. Pertimbangan ini diambil atas berbagai faktor yang akan memperlancar pengumpulan data dalam penelitian seperti proses dalam pengambilan data, penggunaan dana yang tidak terlalu besar serta penghematan waktu dan tenaga yang dipergunakan. Sumber data penelitian ini meliputi data sekunder yaitu data yang diperoleh dari website Bursa Efek Indonesia (www.idx.co.id) berupa laporan keuangan perusahaan manufaktur LQ-45 periode 2015-2017.

$$
\text { Tabel } 1
$$

Data Sampel Perusahaan Manufaktur LQ-45 Periode Tahun 2015-2017

\begin{tabular}{cc}
\hline No. & Nama Perusahaan \\
\hline 1 & PT. Astra Agro Lestari Tbk \\
2 & PT. Adaro Energy Tbk \\
3 & PT. Astra Internasional Tbk \\
4 & PT. Alam Sutera Realty Tbk \\
5 & PT. Ciputra Development \\
6 & PT. Gudang Garam Tbk \\
7 & PT. Indofood Sukses Makmur Tbk \\
8 & PT. Semen Indonesia (Persero) Tbk \\
9 & PT. United Tractors Tbk \\
10 & PT. Unilever Indonesia Tbk \\
\hline
\end{tabular}

Sumber: Data diolah SPSS 21.00 (2019)

Metode analisis data menggunakan analisis multivariat, yaitu analisis yang berhubungan dengan cara yang dipergunakan dalam pengolahan data dengan menggunakan statistik dalam upaya mencapai tujuan dari suatu penelitian yang menggunakan pendekatan inferensial (Santosa, 2020, hal. 3). Analisis ini mempergunakan teknik regresi linear berganda dengan bantuan program Statistical Package for Social Science (SPSS) Versi 21.

Tahapan analisis data dilakukan antara lain: (i) analisis perputaran modal kerja dan profitabilitas melalui uji deskriptif statistik; (ii) uji asumsi klasik dengan normalitas, multikolinearitas, heteroskedastisitas dan uji autokorelasi; dan (iii) analisis regresi berganda dengan persamaan $\mathrm{Y}=\mathrm{a}+\mathrm{b}_{1} \mathrm{X}_{1}+\mathrm{b}_{2} \mathrm{X}_{2}++\mathrm{b}_{3} \mathrm{X}_{3}$; (iv) koefisien determinasi $\left(\mathrm{R}^{2}\right)$ untuk mengetahui seberapa besar kemampuan variabel independen menjelaskan variabel dependen; (v) uji Koefisien Regresi Secara Parsial (Uji t) dengan syarat apabila $t$ hitung $>t$ tabel maka variabel $X$ secara parsial atau individual berpengaruh terhadap variabel $\mathrm{Y}$ atau sebaliknya; dan (vi) uji koefisien regresi secara simultan dengan syarat apabila $\mathrm{f}$ hitung $>\mathrm{f}$ tabel atau menghasilkan probabilitas signifikansi kurang dari alpha 5 persen maka variabel $\mathrm{X}$ berpengaruh terhadap variabel $\mathrm{Y}$ atau sebaliknya.

\section{HASIL DAN PEMBAHASAN}

\section{Statistik Deskriptif}

Tabel 2

Hasil Statistik Deskriptif

\begin{tabular}{cccc}
\hline \multicolumn{4}{c}{ Descriptive Statistics } \\
\hline & Mean & Std. Deviation & $\mathrm{N}$ \\
Perputaran kas (X1) & 82.7960 & 149.29113 & 30 \\
Perputaran piutang (X2) & 11.4053 & 10.14447 & 30 \\
Perputaran persediaan (X3) & 9.3680 & 10.51059 & 30 \\
ROA (Y) & 9.7680 & 9.53694 & 30 \\
\hline
\end{tabular}


Sumber: Output SPSS 21.00 (2018)

Tabel 2 di atas menyajikan data pada 10 perusahaan manufaktur LQ-45 selama periode 20152017 dengan variabel ROA (Y) memiliki skor rata-rata 9,77\%, hal ini menandakan bahwa imbas hasil atas aset perusahaan relatif tinggi. Variabel perputaran kas (X1) memiliki skor rata-rata 82,80 kali, artinya efisiensi atas penggunaan kas dan semakin cepat kembalinya kas masuk pada perusahaan. Variabel perputaran piutang (X2) memiliki skor rata-rata 11,41 kali, artinya jangka waktu atas piutang dagang yang beredar dan semakin besar rasio tidak tertagihnya piutang. Variabel perputaran persediaan (X3) memiliki skor rata-rata 9,37 kali, artinya jangka waktu atas perputaran persediaan dan semakin cepat atau menandakan semakin efektifnya arus pergerakan persediaan.

\section{Uji Asumsi Klasik}

Tabel 3

Hasil Uji Kolmogorov-Smirnov Z

\begin{tabular}{ccc}
\hline & Kolmogorov-Smirnov $\boldsymbol{Z}$ & Probabilitas Signifikansi \\
\hline Skor Residual & 0,467 & 0,981 \\
\hline
\end{tabular}

Sumber: Data diolah SPSS 21.00 (2019)

Tabel 3 di atas menyajikan skor Kolmogorov-Smirnoz Z sebesar 0,467 dengan probabilitas signifikansi yaitu 0,981 (lebih besar dari 0,05), yang artinya nilai residual telah memenuhi asumsi normalitas.

Tabel 4

Hasil Uji Multikolinearitas

\begin{tabular}{ccc}
\hline Variebel & Nilai VIF & Nilai Tolerance \\
\hline Perputaran kas (X1) & 1,047 & 0,955 \\
Perputaran piutang (X2) & 1,019 & 0,981 \\
Perputaran persediaan (X3) & 1,065 & 0,939 \\
\hline
\end{tabular}

Sumber: Data diolah SPSS 21.00 (2019)

Tabel 4 di atas menghasilkan skor variance inflation factor (VIF) yang kurang dari 10 dan skor tolerance yang jauh lebih besar dari angka 1 untuk ketiga variabel independen, yang artinya tidak ada permasalahan multikolinearitas yang terjadi antar variabel independen.

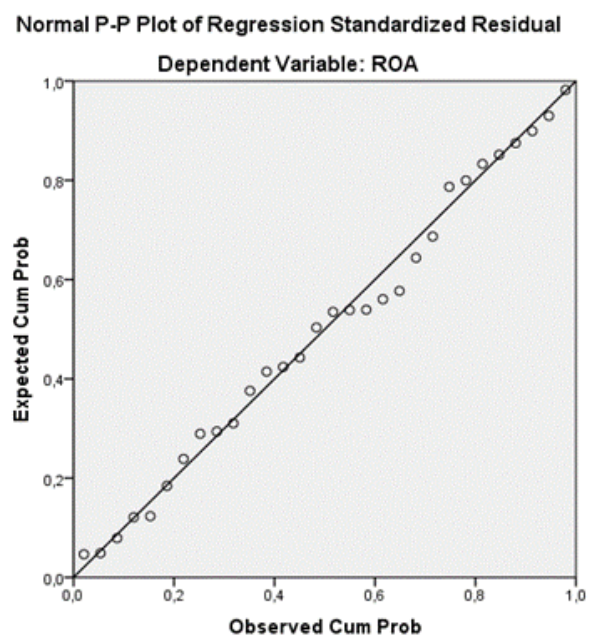

Gambar 2

Hasil p-plots

Gambar 2 memperlihatkan sebaran p-plots yang dengan titik-titik menyebar di sekitar garis diagonal, yang artinya tidak terjadi heteroskedastisitas pada model regresi dengan data yang normal. 
Tabel 5

Hasil Uji Autokorelasi

\begin{tabular}{cc}
\hline Skor / Ketentuan & $\mathrm{k}: 3, \mathrm{n}: 30$ \\
\hline $\mathrm{dL}$ & 1,006 \\
$\mathrm{dU}$ & 1,421 \\
$\mathrm{dW}$ & 1,933 \\
\hline
\end{tabular}

Sumber: Data diolah SPSS 21.00 (2019)

Tabel 5 di atas menghasilkan skor dW sebesar 1,933 untuk pengujian autokorelasi, dengan jumlah variabel independen (k) sebanyak 3 (tiga) dan jumlah data observasi (n) sebesar 30 (tiga puluh). Berdasarkan kriteria yang telah ditetapkan untuk syarat autokorelasi, maka masih tidak terdapat autokorelasi baik positif maupun negatif karena skor dW berada di antara skor dU dan skor $4-\mathrm{dU}(1,421<1,933<2,579)$.

\section{Uji Hipotesis}

Tabel 6

Hasil Uji Koefisien Determinasi $\left(\mathrm{R}^{2}\right)$

\begin{tabular}{ccccc}
\hline Model & $\mathbf{R}$ & $\mathbf{R}^{2}$ & Adjusted $\mathbf{R}^{2}$ & SE of the Estimate \\
\hline 1 & $0,973^{\mathrm{a}}$ & 0,947 & 0,941 & 2,31489
\end{tabular}

Sumber: Data diolah SPSS 21.00 (2019)

Tabel 6 di atas memperlihatkan bahwa koefisien determinasi (R2) yang disesuaikan diperoleh sebesar 0,941 , artinya 94,1 persen perubahan dari variabel perputaran modal kerja yang terdiri dari perputaran kas, perputaran piutang dan perputaran persediaan dijelaskan oleh variasi variabel profitabilitas dengan proksi Return On Assets (Y), sisanya 5,9 persen dijelaskan oleh variabel lain yang tidak dirumuskan dalam model regresi ini.

Tabel 7

Rangkuman Hasil Uji-F

\begin{tabular}{cccc}
\hline Model & df & F & Sig. \\
\hline 1 & 3,6 & 155,406 & $0,000^{\mathrm{b}}$ \\
\hline
\end{tabular}

Tabel 7 di atas memperlihatkan bahwa Nilai F-hitung diketahui sebesar 155,406 dengan probabilitas signifikansi 0,15 (lebih kecil dari alpha 5\%), sehingga menolak H0. Variabel perputaran Modal Kerja (X) yang terdiri dari perputaran kas, perputaran piutang dan perputaran persediaan secara simultan berpengaruh signifikan terhadap variabel Profitabilitas (Y).

Tabel 8

Rangkuman Hasil Uji t

\begin{tabular}{cccc}
\hline Model & Koefisien Regresi & t-stats & Sig. \\
\hline (Constant) & 4,121 & 5,177 & 0,000 \\
Perputaran kas (X1) & 0,062 & 20,990 & 0,000 \\
Perputaran piutang (X2) & 0,033 & 0,768 & 0,449 \\
Perputaran persediaan (X3) & 0,016 & 0,330 & 0,707 \\
\hline
\end{tabular}
berikut:

Tabel 8 di atas melalui uji-t (parsial) menghasilkan hasil persamaan regresi berganda sebagai

$\mathrm{Y}=4,121+0,062 \mathrm{X} 1+0,033 \mathrm{X} 2+0,016 \mathrm{X} 3$

Constant: 4,121. Artinya rata-rata kontribusi variabel independen selain X1, X2 dan X3 juga memberikan dampak positif terhadap nilai Y.

X1: 0,062. Artinya X1 memiliki pengaruh positif terhadap Y, jika terjadi kenaikan X1 sebesar 1 persen dan variabel independen lainnya bernilai tetap, maka $\mathrm{Y}$ akan juga mengalami peningkatan sebesar 6,2 persen.

X2: 0,033. Artinya X2 memiliki pengaruh positif terhadap Y, jika terjadi kenaikan X2 sebesar 3,3 persen dan variabel independen lainnya bernilai tetap, maka $Y$ akan juga mengalami peningkatan sebesar 3,3 persen.

X3: 0,016. Artinya X3 memiliki pengaruh positif terhadap Y, jika terjadi kenaikan X3 sebesar 1,6 persen dan variabel independen lainnya bernilai tetap, maka $Y$ akan juga mengalami peningkatan 
sebesar 1,6 persen.

\section{Pembahasan}

Variabel Perputaran Kas (X1) dengan koefisien regresi memiliki pengaruh yang signifikan atas profitabilitas (ROA) yaitu 0,000 (kurang dari 0,05 ), temuan penelitian ini tidak sependapat dengan hasil terdahulu yang menyatakan tidak signifikannya perputaran kas terhadap profitabilitas dengan pengukuran ROA (Sufiana \& Purnawati, 2013; Lestari \& Farida, 2017) serta penggunaan modal kerja dengan proksi leverage atas profitabilitas (Lestari \& Farida, 2017; Arik Santini \& Baskara, 2018). Temuan penelitian ini memberikan gambaran bahwa perusahaan manufaktur LQ-45 menjadikan rasio ini sebagai efektivitas kinerja dalam aktivitas penggunaan kasnya untuk mengukur kinerja dengan imbas hasil perusahaan dalam asetnya. Manajemen juga menjadikan teknik perputaran kas yang tidak hanya dalam tujuan efektivitas melainkan juga memastikan segala hal dan risikonya dalam pembiayaan kegiatan operasional tanpa menggangu kondisi keuangan perusahaan. Oleh karenanya, semakin cepat perputaran kas maka semakin baik profitabilitas perusahaan.

Variabel Perputaran Piutang (X2) dengan koefisien regresi memiliki pengaruh yang tidak signifikan atas profitabilitas (ROA) yaitu 0,449 (lebih besar dari 0,05), temuan penelitian ini sejalan dengan hasil terdahulu yang menyatakan perputaran piutang tidak berpengaruh signifikan terhadap profitabilitas dengan pengukuran ROA (Sufiana \& Purnawati, 2013) sementara tidak sejalan dengan temua perputaran piutang yang berpengaruh signifikan atas profitabilitas (Lestari \& Farida, 2017). Temuan penelitian ini memberikan gambaran bahwa perusahaan manufaktur LQ-45 tidak serta merta menjadikan rasio ini sebagai efektivitas dalam aktivitas perputaran piutangnya, modal kerja ini sangat terkait dengan volume penjualan karena penjualan barang-barang secara kredit sangat dipengaruhi oleh syarat penjualan piutang tersebut yang kadangkala realisasi dari penjualan kredit tidak efektif. Dengan demikian, semakin cepat perputaran piutang maka tidak berdampak secara langsung kepada profitabilitas perusahaan.

Variabel Perputaran Persediaan (X3) dengan koefisien regresi memiliki pengaruh yang tidak signifikan atas profitabilitas (ROA) yaitu 0,707 (lebih besar dari 0,05), temuan penelitian ini tidak sejalan dengan hasil terdahulu yang menyatakan perputaran piutang berpengaruh signifikan terhadap profitabilitas (Sufiana \& Purnawati, 2013; Lestari \& Farida, 2017). Temuan penelitian ini memberikan gambaran bahwa perusahaan manufaktur LQ-45 tidak serta merta menjadikan rasio ini sebagai efektivitas dalam aktivitas perputaran persediaannya, modal kerja ini sangat terkait dengan ketersediaan barang-barang dalam gudang dalam volume tertentu yang sewaktu-waktu dibutuhkan dalam proses produksi atau penjualan tunai maupun kredit. Dengan demikian, semakin cepat perputaran persediaan maka tidak berdampak secara langsung kepada profitabilitas perusahaan.

\section{SIMPULAN}

Kesimpulan penelitian ini adalah Perputaran Kas (X1) berpengaruh signifikan sementara Perputaran Piutang (X2) dan Perputaran Persediaan (X3) dalam mengukur modal kerja tidak berpengaruh signifikan terhadap Profitabilitas dengan proksi Return On Assets (Y), hal ini dapat dipahami bahwa perputaran modal kerja pada perusahaan Manufaktur LQ-45 yang terdaftar di Bursa Efek Indonesia (BEI) dapat menjadi gambaran bahwa modal kerja yang efisien dan efektif sangat menentukan kinerja perusahaan dalam wujud profitabilitas yang dibuktikan dengan nilai adjusted RSquare sebesar 94,1\%. Hasil penelitian ini diharapkan dapat memberikan kontribusi dalam pengujian teori terapan, terutama dalam pengukuran rasio aktivitas dalam analisis laporan keuangan pada bidang akuntansi mengenai pengaruh perputaran kas, perputaran piutang dan perputaran persediaan terhadap profitabilitas yang menggambarkan kinerja perusahaan dan dapat digunakan sebagai acuan untuk penelitian mendatang menggunakan proksi lainnya seperti rasio solvabilitas, rasio profitabilitas dan rasio prospek pasar.

\section{DAFTAR PUSTAKA}

Arik Santini, N. L., \& Baskara, I. G. (2018). Pengaruh Perputaran Modal Kerja, Ukuran Perusahaan dan Likuiditas terhadap Profitabilitas Perusahaan Tekstil dan Garmen. E-Jurnal Manajemen Unud, 7 (12), 6502-6531. Retrieved from https://doi.org/10.24843/EJMUNUD.2018.v07.i12.p05 
Cahyono, L. (2016). Pengaruh antara Biaya CSR (Corporate Social Responsibility) Ukuran Perusahaan, Leverage dan Growth terhadap Profitabilitas pada Perusahaan Pertambangan yang Terdaftar di Bursa Efek Indonesia Periode Tahun 2009-2013. MABISKA Journal, 1(2), 44-61. Retrieved from https:// www.stiebpkp.id/wp-content/uploads/2019/07/44-61_Lukman-Cahyono.pdf

Fahmi, I. (2015). Analisis Laporan Keuangan. Bandung: Alfabeta.

Harahap, S. S. (2018). Analisis Kritis Atas Laporan Keuangan (Cetakan 14). Jakarta: Rajawali Pers, Ekonomi/ Manajemen (Buku Cetak Ulang).

Hery. (2014). Pengendalian A kuntansi dan Manajemen. Jakarta: Penerbit Kencana.

Husain, T., Sarwani, Sunardi, N., \& Lisdawati. (2020). Firm's Value Prediction Based on Profitability Ratios and Dividend Policy. Finance \& Economics Review, 2(2), 13-26. Retrieved from https:// riiopenjournals.com/index.php/finance-economics-review/article/view/102

IAI. (2013). Pernyataan Standar Akuntansi Keuangan. Jakarta: Dewan Standar Akuntansi Keuangan - Ikatan Akuntan Indonesia.

Isfani, Y., Dewi, E. P., \& Husain, T. (2019). Relationships Accounting Treatment of Fixed Assets towards the Fairness of Reporting Financial Statements. European Exploratory Scientific Journal (EESJ), 3(3), 112. Retrieved from https://syniutajournals.com/index.php/EESJ/article/view/136

Kasmir, D. (2016). Analisis Laporan Keuangan. Jakarta: PT. Rajagrafindo Persada.

Lestari, Y., \& Farida, L. (2017). Pengaruh Modal Kerja terhadap Profitabilitas pada Industri Makanan dan Minuman yang Terdaftar di Bursa Efek Indonesia. JOM FISIP, 4(1), 1-13. Retrieved from https:// media.neliti.com/media/publications/130641-ID-none.pdf

Maesaroh, Y., \& Dewi, E. P. (2020). Analisis Akuntansi Persediaan Barang Dagang Berdasarkan PSAK 14 (Studi Kasus Pada PT XYZ-CTP 1). Jurnal Buana Akuntansi, 5(1), 1-14. Retrieved from https:// doi.org/10.36805/akuntansi.v5i1.1016

Munawir, S. (2010). Analisis Laporan Keuangan. Yogyakarta: Liberty.

Novianti, W. (2016). Pengaruh Struktur Aktiva Dan Pertumbuhan Penjualan Terhadap Struktur Modal (DAR) Pada Perusahaan Retail Yang Terdaftar Di Bursa Efek Indonesia Periode 2012-2016. Jurnal Ilmu Keuangan dan Perbankan (JIKA), 5(2), 1-11. Retrieved from https://doi.org/10.34010/jika.v5i2.377

Prasetyono, A. P. (2017, Nopember 13). Persaingan Di Era Globalisasi Dan Ekonomi Digital. Retrieved Maret 29, 2018, from Badan Riset dan Inovasi Nasional: https://www.ristekbrin.go.id/kolom-opini/ persaingan-di-era-globalisasi-dan-ekonomi-digital/

Santosa, A. D. (2020). Analisis Multivariat (Cetakan Keempat) (3 ed.). Yogyakarta: Penerbit Kepel Press.

Sufiana, N., \& Purnawati, N. K. (2013). Pengaruh Perputaran Kas, Perputaran Piutang, dan Perputaran Persediaan terhadap Profitabilitas. E-Jurnal Manajemen Unud, 2(4), 451-468. Retrieved from https://media.neliti.com/media/publications/252877-pengaruh-perputaran-kas-perputaran-piutac9d7b2de.pdf

Sugiyono. (2018). Metode Penelitian Evaluasi: Pendekatan Kuantitatif, Kualitatif, dan Kombinasi. Bandung: CV. Alfabeta.

Yanti. (2018). Analisa Pengaruh Faktor-Faktor Pembentuk Fee Ijarah (PSAK 107) Terhadap Portofolio Rahn Emas Di Bank Syariah. Jurnal Buana Akuntansi, 3(1), 24-55. Retrieved from https:// doi.org/10.36805/akuntansi.v3i1.226 